\title{
7. nasjonale konferanse om selvmordsforskning og -forebygging
}

\author{
Intervju med Lars Mehlum, leder av programkomiteen
}

Ved Hilde Matre Larsen

7. nasjonale konferanse om selvmordsforskning og -forebygging arrangeres 4. og 5. april 2011. Tema for konferansen er "Psykoterapeutiske intervensjoner i selvmordsforebygging". Stedet er Oslo, arrangør er Nasjonalt senter for selvmordsforskning og -forebygging (NSSF) i samarbeid med Landsforeningen for etterlatte ved selvmord (LEVE).

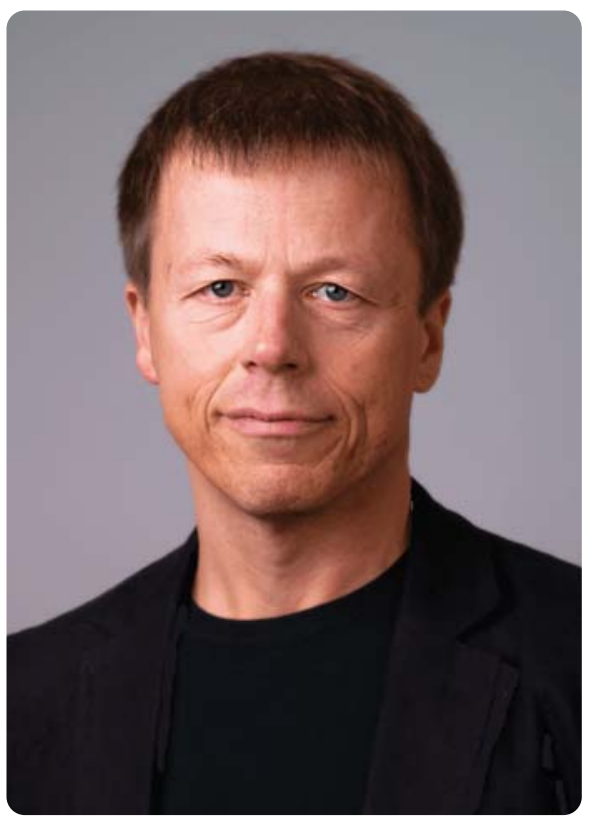

Lars Mehlum

\section{Hvordan startet disse konferansene?}

- Det hele startet med Handlingsplan mot selvmord, i 1997. Den første konferansen ble arrangert i Oslo, av Statens helsetilsyn. Den var en aktørkonferanse, rettet mot fylkesleger, fagfolk og -miljøer og prosjektledere. 2. nasjonale konferanse var det NSSF som arrangerte - på forespørsel fra Helstetilsynet. Den ble også arrangert i Oslo, i 1999, og er den største nasjonale suicidologiske konferansen som hittil er arrangert i Norge, med 8 paralleller og 50 foredrag.
Hvordan finansieres konferansene?

- Konferansene er blitt st $\varnothing$ ttet av Helsedirektoratet, lokale og regionale støttespillere, samt ved deltakernes egen betaling. Vi har ingen kommersiell sponsing av konferansene.

Hva er målet med disse konferansene?

- Hovedhensikten med konferansene er å sette selvmordsforskning og -forebygging på den faglige, allmennmenneskelige og politiske dagsorden og formidle oppdaterte kunnskaper om selvmordsforebygging. Konferansene er også med på å bygge faglige nettverk på tvers av profesjoner, organiasjoner og regioner.

Hvordan er konferansene strukturert?

- Konferansene arrangeres annethvert år. De fleste i Norge som kan noe om tematikken, har vært her og holdt foredrag. Hver gang inviterer vi en eller flere foredragsholdere fra utlandet for å få nye impulser utenfra. Mange av de utenlandske foredragsholderne holder også workshops. I tillegg til i Oslo, har vi arrangert konferansene i Bergen, Troms $\varnothing$, Lillehammer og Trondheim, i samarbeid med lokale ressursmiljøer.

Hva er hensikten med a forflytte konferansene geografisk?

- Det er viktig å dele på godene! Også andre steder i Norge enn Oslo kan trenge den profileringseffekten disse konferan- sene gir. At en slik konferanse arrangeres nær der du bor, kan $\varnothing$ ke tilgjengeligheten. Faglig sett har NSSF alltid har hatt en finger med i spillet i programmet, men det er jo ikke slik at det bare er i Oslo man finner relevante fagmiljøer og gode ideer.

Kan du si litt om neste års konferanse?

- Tema for 7. nasjonale konferanse er "Psykoterapeutiske intervensjoner i selvmordsforebygging". Vi tror dette temaet vil være relevant for alle som driver med selvmordsforskning og -forebygging. Vi ønsker å fokusere på hvordan vi systematisk kan utnytte samspillet i topersonforhold og grupper. For behandlere tror vi konferansetemaet vil være særlig aktuelt fordi suicidalitet er en så sentral del av problematikken for mange som $s \varnothing$ ker hjelp i det psykiske helsevernet. Vi har invitert to professorer fra USA med to forskjellige kliniske aspekter til konferansen - Katherine Shear og Barbara Stanley, samt sentrale norske psykoterapiforskere som arbeider med behandlingsmetoder relevante for suicidalitetsproblematikken.

Hvem retter konferansen seg mot?

- Målgruppen er helsearbeidere i alle deler av tjenesteapparatet som er i kontakt med mennesker med suicidal adferd eller med etterlatte ved selvmord.

Tidligere nasjonale konferanser om selvmordsforskning og -forebygging:

\begin{tabular}{|l|l|l|l|}
\hline Nr. & Ar & Sted & Tema \\
\hline $\mathbf{1}$ & 1997 & Oslo & Forskning og forebygging av selvmord \\
\hline $\mathbf{2}$ & 1999 & Oslo & Bygge og forebygge \\
\hline $\mathbf{3}$ & 2002 & Bergen & Kliniske utfordringer i selvmordsforebygging \\
\hline $\mathbf{4}$ & 2005 & Troms $\varnothing$ & Villet egenskade blant ungdom - fra forståelse til forebygging \\
\hline $\mathbf{5}$ & 2007 & Lillehammer & Vold, traumer og forebygging av selvmord \\
\hline $\mathbf{6}$ & 2009 & Trondheim & Fra forskning til klinikk \\
\hline $\mathbf{7}$ & 2010 & Oslo & Psykoterapeutiske intervensjoner i selvmordsforebygging \\
\hline
\end{tabular}


Katherine Shear M.D. is Marion E. Kenworthy Professor of Psychiatry at Columbia University. She graduated with Honors from the University of Chicago, completed medical school at Tufts University and is Board Certified in both internal medicine and psychiatry and neurology and author of more than 200 peer-reviewed papers. She previously served on the faculty of the Department of Psychiatry at Cornell University and the University of Pittsburgh. She developed and tested the first treatment targeting complicated grief, and is currently testing this treatment in two additional NIMH-funded studies, both of which include suicide survivors.

Barbara Stanley PhD er gjesteprofessor ved NSSF siden 2008. Hun er også professor i klinisk psykologi ved Department of Psychiatry, Columbia University, New York og forsker ved New York State Psychiatric Institute. Hun er også leder for Center on Intervention for Prevention of Suicide ved Columbia University og er redaktør for Archives of Suicide Research. Hun har utført flere intervensjonsstudier rettet mot suicidalitet blant ulike pasientgrupper, slik som pasienter med ustabil personlighetsforstyrrelse og selvskading og suicidalitet blant ungdom.

Sigmund Karterud er professor i psykiatri ved Universitet i Oslo og avdelingsoverlege ved Avdeling for Personlighetspsykiatri ved Oslo Universitetssykehus. Han har skrevet en rekke lærebøker, om selvpsykologi, gruppeanalyse og psykodynamisk gruppepsykoterapi, dagavdelingsbehandling, personlighetspsykiatri og sist (sammen med Anthony Bateman) en manual for mentaliseringsbasert terapi (MBT) og MBT vurderingsskala, versjon individualterapi. Han leder en nordisk gruppe for utvikling av MBT i Norden.

Pravin Israel er psykologspesialist og seniorforsker ved FoU-avdeling Psykisk Helsevern, Akershus Universitetssykehus (Ahus). Han har mange års erfaring fra klinisk arbeid med barn og familier, noe som har inspirert hans forskning. Nylig avsluttet han en RCT-studie om tilknytningsbasert familieterapi for deprimerte ungdommer. Han er opptatt av utprøving og implementering av evidensbaserte intervensjoner i vanlig klinisk praksis og koordinerer en forskergruppe ved Ahus som har depresjon hos barn og ungdom som sitt satsingsområde. Videre er han involvert i forskningsevaluering av en storstilt nasjonal implementering av Assertive Community Treatment (ACT) i Norge.

Lars Mehlum er professor i psykiatri og suicidologi ved Universitetet i Oslo og grunnlegger og leder for Nasjonalt senter for selvmordsforskning og -forebygging ved Institutt for klinisk medisin. Han har stått sentralt i utviklingen av nasjonale strategier for selvmordsforebygging i Norge siden starten i 1993. Han har hatt en rekke nasjonale og internasjonale lederverv, bl.a. har han vært president for IASP (International Association for Suicide Prevention) og rådgiver for WHO og i nasjonale strategier for selvmordsforebygging i en rekke land. Han er redaktør for tidsskriftet Suicidologi, samt medredaktør for flere andre tidsskrifter. Videre har han publisert mer enn 150 forskningsartikler, bokkapitler og fagbøker. Mehlum leder utdanningsprogrammet i Dialektisk atferdsterapi i Norge samt en større randomisert kontrollert studie av effekten av DBT tilpasset for selvskadende og suicidale ungdommer.

\title{
7. nasjonale konferanse om selvmordsforskning og -forebygging
}

\author{
Tid: 4.-5. april 2011
}

Sted: Clarion Royal Christiania Hotel, OSLO 